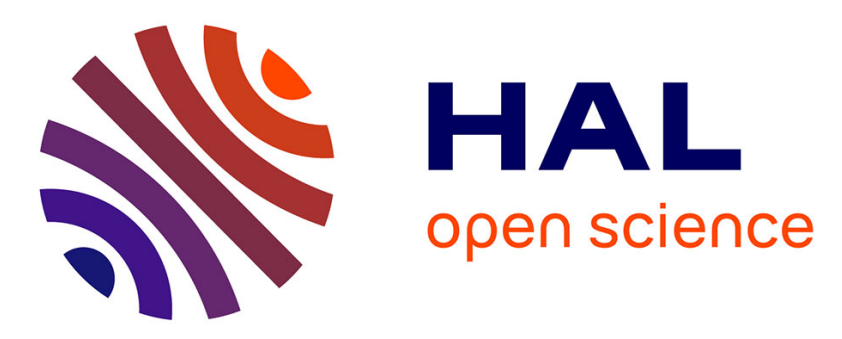

\title{
Catalytic behavior of surfactant-containing-MCM-41 mesoporous materials for cycloaddition of 4-nitrophenyl azide
}

Bouhadjar Boukoussa, Sarah Zeghada, Ghenia Bentabed-Ababsa, Rachida Hamacha, Aïcha Derdour, Abdelkader Bengueddach, Florence Mongin

\section{To cite this version:}

Bouhadjar Boukoussa, Sarah Zeghada, Ghenia Bentabed-Ababsa, Rachida Hamacha, Aïcha Derdour, et al.. Catalytic behavior of surfactant-containing-MCM-41 mesoporous materials for cycloaddition of 4-nitrophenyl azide. Applied Catalysis A: General, 2015, 489, pp.131-139. 10.1016/j.apcata.2014.10.022 . hal-01096627

\section{HAL Id: hal-01096627 \\ https://hal-univ-rennes1.archives-ouvertes.fr/hal-01096627}

Submitted on 2 Jul 2015

HAL is a multi-disciplinary open access archive for the deposit and dissemination of scientific research documents, whether they are published or not. The documents may come from teaching and research institutions in France or abroad, or from public or private research centers.
L'archive ouverte pluridisciplinaire HAL, est destinée au dépôt et à la diffusion de documents scientifiques de niveau recherche, publiés ou non, émanant des établissements d'enseignement et de recherche français ou étrangers, des laboratoires publics ou privés. 

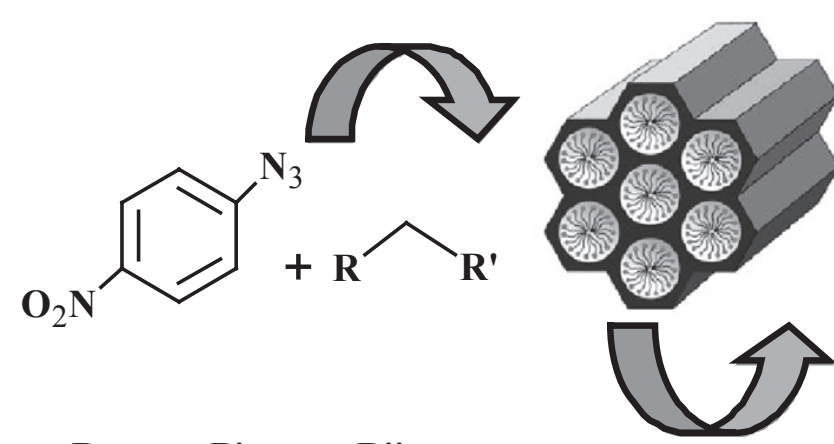<smiles>[R]c1nnn(-c2ccc([N+](=O)[O-])cc2)c1[R]</smiles>

R $\mathbf{R}^{\prime} \quad \mathbf{R}^{\prime \prime}$

COMe COMe Me

$\mathrm{COMe} \mathrm{CO}_{2} \mathrm{Me} \mathrm{Me}$

$\mathrm{COMe} \mathrm{CO}_{2} \mathrm{Et} \mathrm{Me}$

COPh COPh Ph

$\begin{array}{lll}\mathrm{CN} & \mathrm{CN} & \mathrm{NH}_{2}\end{array}$

2 


\section{$5 \quad$ Highlights}

6

7 Synergic effect between homogeneous and heterogeneous catalyst in cycloaddition

8 reactions

9 A facile method for synthesis of triazoles in very short durations (15min).

10

Superior catalytic activity and reusability of as-synthesized Si-MCM-41.

11

12 


\section{Catalytic behavior of surfactant-containing-MCM-41 mesoporous materials} For cycloaddition of 4-nitrophenyl azide
Bouhadjar Boukoussa ${ }^{\mathrm{a}}$, Sarah Zeghada ${ }^{\mathrm{b}}$, Ghenia Bentabed Ababsa ${ }^{\mathrm{b}}$, Rachida Hamacha, ${ }^{\mathrm{a}}$, Aïcha Derdour ${ }^{\mathrm{b}}$, Abdelkader Bengueddach ${ }^{\mathrm{a}}$, Florence Mongin ${ }^{\mathrm{c}}$

${ }^{a}$ Laboratoire de Chimie des Matériaux L.C.M, Université d'Oran, BP 1524 El-Mnaouer, 31000 Oran, Algeria

${ }^{\mathrm{b}}$ Laboratoire de Synthèse Organique Appliquée L.S.O.A, Université d'Oran, BP 1524 ElMnaouer, 31000 Oran, Algeria

' Equipe Chimie et Photonique Moléculaires CPM, Institut des Sciences Chimiques de Rennes, UMR 6226, Université de Rennes 1-CNRS, Bâtiment 10A, Case 1003, Campus Scientifique de Beaulieu, 35042 Rennes Cedex, France

*corresponding author: Rachida Hamacha: hamacha.rachida@univ-oran.dz 
Abstract:

Si-MCM-41, Ga-MCM-41 and Al-MCM-41 mesoporous catalysts (with $\mathrm{Si} / \mathrm{Al}=80$ and $\mathrm{Si} / \mathrm{Ga}=80$ ) were prepared by direct synthesis under hydrothermal crystallization method using sodium aluminate or gallium sulfate and tetraethyl orthosilicate (TEOS) as aluminum or gallium and silica sources, respectively. The structural features of the materials were determined by various physico-chemical techniques such as X-ray diffraction (XRD), nitrogen sorption at $77 \mathrm{~K}$, Fourier transform infrared spectroscopy (FTIR), scanning and transmission electronic microscopy (SEM, TEM) and thermogravimetric analysis ATG. The catalytic activity of the calcined and as-synthesized catalyst was evaluated through the cycloaddition reaction of 4-nitrophenyl azide with activated alkenes at room temperature under liquid-phase conditions. High yields of 1,2,3-triazole were obtained. For comparison purpose, mixtures of homogeneous and heterogeneous catalyst $\mathrm{Et}_{3} \mathrm{~N} / \mathrm{M}-\mathrm{MCM}-41(\mathrm{M}=\mathrm{Al}$ or Ga) are also tested. The catalyst was used in five consecutive experiments without important loss of activity, confirming its stability. Finally, a new method for preparing triazoles in short reaction times was developed.

Keywords: mesoporous silica, MCM-41, cycloaddition reaction, triazoles synthesis, surfactant, catalyst re-use.

\section{Introduction}

The discovery of ordered mesoporous materials M41S by Mobil in 1992 [1] has attracted intense interest due to their large surface areas, well-defined pore structures, inert framework, non toxicity and high biocompatibility [2]. These catalysts are completely recovered after reaction by filtration and are also easily regenerated [3]. The lack of hydrothermal stability of the mesoporous materials has been overcome by the incorporation of heteroatoms such as Al, Ga, Ti, Fe, V, W and Cr [4-7]. These properties allow these mesoporous materials to be used 
in a wide range of applications such as catalysis [4-7], adsorption [8,10], extraction [11], energy [12], drug delivery systems [13], and for their luminescent character [14].

MCM-41 mesoporous materials have drawn the attention of researchers because of their rapid and easy synthesis [15]. Possessing regular pore structure, uniform pore diameter and high surface area [16], they have successfully been employed for typical acid-base or oxidoreduction catalysis such as dehydrogenation of $n$-butane [17], hydrodesulfurization of 4,6dimethyldibenzothiophene [18], synthesis of benzo[ $\alpha$ ]xanthenone derivatives [19], oxidation of alcohols and toluene [20], tert-butylation of hydroquinone [21], Beckmann rearrangement reaction [22], and cyclohexanone oxime rearrangement [23].

Recently several approaches have been proposed to develop basicity in mesoporous materials by dispersing alkali metal oxides in the channel [24,25]. Kloetstra et al. [26] initially proposed to disperse cesium oxide particles in Si-MCM-41 pores. However, due to the treatments used throughout the preparation, its structure was extensively damaged [26]. Another way to get basic Si-MCM-41 sites is by functionalizing its surface with organic compounds, particularly with those containing terminal amines in their composition $[27,28]$. These procedures, which are used to generate basic sites on Si-MCM-41, are hard to process and not always lead to the planned basic sites, stable enough for catalysis application. Roy et al [29] have synthesized a new pyridine-imine functionalized mesoporous silica (SBA-15) followed by the grafting of $\mathrm{Cu}(\mathrm{II})$ for obtaining a new $\mathrm{Cu}$-PyIm-SBA-15 material and they used these solids like basic catalysts for synthesis of 1,4-disubstituted 1,2,3-triazole.

The material is functionalized by anchoring organic bases at the silanol groups, thereby forming a covalent bond. Unfortunately, these organic-inorganic hybrid materials are less basic than the corresponding free organic amine molecule. This fact has been explained as involving the interaction of the amine function with residual silanol groups [30]. 
Mesoporous solids may be used without calcination, the presence of surfactant inside the pores showing interesting and remarkable basic properties. Thus, these attractive catalysts have also been tested in different reactions which require basic catalysts such as Knoevenagel and Claisen-Schmidt condensations [31], Michael additions [32], and cycloaddition reactions of $\mathrm{CO}_{2}$ with epoxides [33].

Kubota et al. [32,34] achieved excellent results during Knoevenagel condensation by using Si-MCM-41 molecular sieve while keeping the surfactant inside the pores called [CTA]SiMCM-41. In this catalyst, active sites are high basicity $\mathrm{SiO}^{-}$sites, which are in the channels. Oliveira and al [35] used a series of as-synthesized molecular sieves containing several Si/Al ratio and they have been tested as basic catalysts for Knoevenagel condensation, they showed that increasing the content of $\mathrm{Si} / \mathrm{Al}$ ratio increases the amount of siloxy anion and increases conversion of benzaldehyde.

1,2,3-Triazoles have found widespread applications as pharmaceuticals and industrial compounds such as dyes, anticorrosive agents, photostabilizers, photographic materials, and agrochemicals [36]. In addition, compounds containing 1,2,3-triazoles have shown a broad spectrum of biological activities such as antibacterial against Gram positive bacteria [37], herbicidal and fungicidal [38], antiallergic [39], anticonvulsant [40], $\beta$-lactamase inhibitive [41] and anti-HIV [42]. Several synthetic methods for preparing triazole derivatives have been developed. Among them, we can cite Huisgen 1,3-dipolar cycloaddition [43] and its recent development towards click chemistry [44].

In this paper, we report a facile and rapid pathway for the synthesis of 1,2,3-triazoles through 1,3-dipolar cycloaddition reactions between 4-nitrophenyl azide and activated alkenes [36] using a heterogeneous catalytic system.

In previously reported works concerning MCM-41-catalyzed Knoevenagel condensation reactions, as-synthesized Si-MCM-41 was studied as basic catalyst [31-33]. Generally the 
catalysts for the cycloaddition of azide are solids which contain copper [29,45-47], to our best knowledge, mesoporous Si- Ga or Al-MCM-41 have never been studied for cycloaddition of aryl azides. Thus the aim of the present research is to compare the catalytic properties of a series of mesoporous catalyst including: (1) Si-MCM-41, (2) Ga-MCM-41, (3) Al-MCM-41, (4) and a mixture between homogeneous/heterogeneous catalysts.

These mesoporous materials are used as-synthesized or calcined like catalysts for the cycloaddition of aryl azides with activated alkenes in liquid phase at room temperature.

\section{Experimental}

\subsection{Synthesis of Ga-MCM-41 and Al-MCM-41}

Si-MCM-41, Ga-MCM-41 and Al-MCM-41 mesoporous materials were prepared by direct hydrothermal synthesis using cetyltrimethylammonium bromide (CTAB) as structuredirecting template, gallium sulfate or sodium aluminate and TEOS as the gallium or aluminum and silica source, respectively. The procedure for the catalysts preparation was thoroughly described elsewhere [8].

The gel composition was: 1 TEOS, $0.12 \mathrm{CTAB}, 0.25 \mathrm{NaOH}, 1.5 \mathrm{EtOH}, 100 \mathrm{H}_{2} \mathrm{O}$ and $0.00625 \mathrm{Ga}_{2}\left(\mathrm{SO}_{4}\right)_{3}$ (case of Ga-MCM-41) or $0.00625 \mathrm{Al}_{2} \mathrm{O}_{3}$ (case of Al-MCM-41) (for the case of $\mathrm{Si}-\mathrm{MCM}-41$ the $\mathrm{Si} / \mathrm{Al}$ or $\mathrm{Ga} \approx \infty)$. We first prepared two solutions, the first by mixing CTAB (2.91 g, 98\%, Alfa Aesar), distilled water (110 mL) and ethanol (6 mL, 99.5\%, Riedelde-Haën) and stirring for $15 \mathrm{~min}$ at $308 \mathrm{~K}$, and the second solution by mixing $\mathrm{NaOH}(0.66 \mathrm{~g}$, 98\% Sigma-Aldrich), distilled water $(10 \mathrm{~mL})$, and the appropriate amount of sodium aluminate $\left(54 \% \mathrm{Al}_{2} \mathrm{O}_{3}, 41 \% \mathrm{Na}_{2} \mathrm{O}, 5 \% \mathrm{H}_{2} \mathrm{O}\right.$, Aldrich) or gallium sulfate $\left(\mathrm{Ga}_{2}\left(\mathrm{SO}_{4}\right)_{3}, 99.99 \%\right.$, Sigma-Aldrich). TEOS (7.4 mL, 98\%, Aldrich) and the second solution were added dropwise to the first solution. After ageing at $308 \mathrm{~K}$ for $3 \mathrm{~h}$, the obtained mixture was transferred to an autoclave and hydrothermally treated under autogenous pressure at $423 \mathrm{~K}$ for $10 \mathrm{~h}$. The 
obtained product was then removed from the oven and cooled to room temperature. After filtration and washing several times with distilled water, the obtained solid was dried at $333 \mathrm{~K}$ for at least $24 \mathrm{~h}$. The powder was then calcined in air at $823 \mathrm{~K}$ for $12 \mathrm{~h}$ to remove the template.

\subsection{Characterization}

The XRD powder diffraction patterns of the Si-MCM-41, Ga-MCM-41 and Al-MCM-41 mesoporous materials were obtained with a Bruker AXS D-8 diffractometer using $\mathrm{Cu}-\mathrm{K} \alpha$ radiation. Nitrogen adsorption was performed at $77 \mathrm{~K}$ in a TriStar $3000 \mathrm{~V} 6.04$ A volumetric instrument. The samples were outgassed at $353 \mathrm{~K}$ prior to the adsorption measurement until a $3 \times 10^{-3}$ Torr static vacuum was reached. The surface area was calculated by the BrunauerEmmett-Teller (BET) method [48]. The pore size distributions were obtained from the adsorption branch of the isotherm using the Barrett-Joyner-Halenda (BJH) method [49]. FTIR spectra of the mesoporous Al, Ga or Si-MCM-41 molecular sieves in the range 400$4000 \mathrm{~cm}^{-1}$ were collected on a JASCO (4200) instrument using $\mathrm{KBr}$ pellet technique. Thermogravimetric analysis (LABSYS Evo SETARAM) was carried out under air atmosphere in the temperature range $20-800^{\circ} \mathrm{C}$ with a heating rate of $10^{\circ} \mathrm{C} / \mathrm{min}$. The energy dispersive X-ray analysis (EDX) jointed to a XL-30 scanning electron microscope was used to calculate the $\mathrm{Si} / \mathrm{Al}$ and $\mathrm{Si} / \mathrm{Ga}$ ratios of the aluminum- or gallium-containing MCM-41. The surface topography of the different solids was observed using SEM on a Hitachi 4800S microscope and TEM was performed on a JEOL 1200 EXII device.

\subsection{Reaction procedures for the cycloaddition of 4-nitrophenyl azide with activated alkenes}

Procedure 1. To the required methylene-activated compound (2 mmol) and $\mathrm{Et}_{3} \mathrm{~N}(2$ mmol) in DMF (2 mL) was added 4-nitrophenyl azide (1, $1 \mathrm{mmol})$, and the mixture was 
stirred at room temperature for $24 \mathrm{~h}$. The precipitate formed upon addition of $\mathrm{H}_{2} \mathrm{O}(5 \mathrm{~mL})$ was filtrated, washed with $\mathrm{H}_{2} \mathrm{O}$, dried, and recrystallized from $\mathrm{iPrOH}$.

Procedure 2. To the required methylene-activated compound ( $2 \mathrm{mmol})$ and $\mathrm{Et}_{3} \mathrm{~N}$ (2 mmol) in DMF (2 mL) was added 4-nitrophenyl azide (1, $1 \mathrm{mmol})$ and calcined or assynthesized mesoporous $\mathrm{Si}-\mathrm{Ga}$ - or Al-MCM-41 catalyst (10 mol\%), and the mixture was stirred at room temperature (TLC monitoring). The precipitate formed upon addition of $\mathrm{H}_{2} \mathrm{O}$ ( $5 \mathrm{~mL}$ ) was filtrated, washed with $\mathrm{H}_{2} \mathrm{O}$ and dried. To remove the catalyst, the precipitate was extracted with acetone. After removal of the solvent, the crude product was recrystallized from iPrOH. Characterization data associated with this article have been previously described [50], except in the case of $\mathbf{3 c}$.

The characterisation data for the $3 c$ is as fellow Ethyl 5-methyl-1-(4-nitrophenyl)1H-1,2,3-triazole-4-carboxylate (3c). Yield: 93\% (procedure 1). Yellow powder, mp 185 ${ }^{\circ} \mathrm{C} .{ }^{1} \mathrm{H}$ NMR (300 MHz, $\left.\mathrm{CDCl}_{3}\right): 1.45$ (t, 3H, H1, J= $\left.7.1 \mathrm{~Hz}\right), 2.68$ (s, 3H, H6), 4.47 (q, 2H, $\mathrm{H} 2, J=7.1 \mathrm{~Hz}), 7.73(\mathrm{~d}, 2 \mathrm{H}, J=9.1 \mathrm{~Hz}), 8.46(\mathrm{~d}, 2 \mathrm{H}, J=9.1 \mathrm{~Hz}) .{ }^{13} \mathrm{C} \mathrm{NMR}(75 \mathrm{MHz}$, $\left.\mathrm{CDCl}_{3}\right)$ : $10.4\left(\mathrm{CH}_{3}\right), 14.5\left(\mathrm{CH}_{3}\right), 61.5\left(\mathrm{CH}_{2}\right), 125.3(2 \mathrm{CH}), 126.0(2 \mathrm{CH}), 137.6(\mathrm{C}), 139.0$ (C), $140.4(\mathrm{C}), 148.4(\mathrm{C}), 161.5(\mathrm{C}=\mathrm{O})$.

Procedure 3. To the required methylene-activated compound (2 mmol) in DMF (2 $\mathrm{mL})$ was added 4-nitrophenyl azide (1, $1 \mathrm{mmol})$ and as-synthesized mesoporous MCM-41 catalyst $(25 \mathrm{~mol} \%$ ), the mixture was stirred at room temperature (TLC monitoring). The next steps are as above (procedure 2).

\section{Results and discussion}

\subsection{Characterization of the catalysts}

The diffraction patterns of the as-synthesized and calcined Si-MCM-41, Ga-MCM-41 and Al-MCM-41 catalysts are given in Fig. 1. The main peaks of the XRD patterns of all the 
samples are consistent with the characteristic peaks of the hexagonal structure of the MCM-41 mesoporous molecular sieves. Si-MCM-41 and Al-MCM-41 exhibits a strong peak respectively at $2 \theta=2.27-2.13$ due to (100) reflection lines and three weak signals around 3.94-3.65, 4.56-4.18 and 6.01-5.50 (20) corresponding to (110), (200) and (210) reflections, indicating the formation of well-ordered mesoporous materials with hexagonal regularity [51]. For Ga-MCM-41 materials, peaks of XRD are broadened as a result of the insertion of amount of Ga. This suggests a more disordered arrangement of channels for the Ga-MCM-41, but keeping a hexagonal structure with good regularity. Similar observations have been shown by Campos et al where they studied the influence of $\mathrm{Si} / \mathrm{Ga}$ on the structure of MCM-41 [9]. The decrease of structure order for Al MCM-41 and particularly for Ga-MCM-41 can be explained by the isomorphous substitution of $\mathrm{Ga}$ or $\mathrm{Al}$ in MCM-41 framework carried out by a direct synthesis method. [52,53].

The unit cell parameter $\mathrm{a}_{0}$ is calculated from $\mathrm{a}_{0}=2 \mathrm{~d}_{100} / \sqrt{3}$, where the $\mathrm{d}$-spacing values are calculated by $\mathrm{n} \lambda=2 \mathrm{~d} \sin \theta$. The observed $\mathrm{d}$ spacing and unit cell parameter results (Table 1 ) are well-matched with the hexagonal p6mm space group.

We notice that the calculated cell parameters are 43, 47 and $48 \AA$ for Si- Al- or Ga-MCM41 solids, respectively; these results are consistent with the literature, where it has been showed that the incorporation of a heteroatom in the structure of MCM-41 increases the unit cell parameter [9]. This difference is probably due to the bond length of $\mathrm{Ga}-\mathrm{O}, \mathrm{Al}-\mathrm{O}$ and $\mathrm{Si}-$ $\mathrm{O}$, Ga-O being higher than $\mathrm{Al}-\mathrm{O}$ and $\mathrm{Si}-\mathrm{O}$ as consequence of the larger ionic radius of $\mathrm{Ga}^{3+}$ than $\mathrm{Al}^{3+}$ and $\mathrm{Si}^{4+}$ [54]. The change in $\mathrm{d}$-spacing and unit cell parameter compared to siliceous MCM-41 proved the incorporation of gallium or aluminum in the framework.

An increase of peak intensity is systematically visible after calcination, assessing more ordered structure after surfactant removal. The (100) reflection becomes sharper and more intense upon calcination, although the (110), (200) and (210) reflections are not well defined 
and overlap to give a single broad band. A lattice contraction is also observed after calcination due to surfactant removal and to the condensation of silanol $(\mathrm{SiOH})$ groups in the walls.

Quantitative data for the estimation of gallium and aluminum incorporation was obtained by EDX analysis. According to the chemical composition used for the synthesis of Ga-MCM41 and $\mathrm{Al}-\mathrm{MCM}-41$, a nominal value of $\mathrm{Si} / \mathrm{Ga}$ or $\mathrm{Si} / \mathrm{Al}=80$ was expected. However, the $\mathrm{Si} / \mathrm{Ga}$ and $\mathrm{Si} / \mathrm{Al}$ ratios, as determined by EDX in the calcined MCM-41, are a little higher, indicating that the amount of heteroatom incorporated in the structure is a little less than the expected one (Table 1). For the same ratios of $\mathrm{Si} / \mathrm{Ga}$ or $\mathrm{Si} / \mathrm{Al}$, the percentage of aluminum in Al-MCM-41 is much more than gallium in Ga-MCM-41. This difference of the gallium content in the starting gel and in the final product has already been revealed by Lin et al (2005) when studying the effect of gallium content in the synthesis of hexagonal silicas. In fact, the yield of $\mathrm{Ga}$ in the synthesized solids decreased to around $60 \%$ [55].

In Table 1, are also given the BET surface area, pore size, wall thickness and pore volume of the calcined Si- Ga- or Al-MCM-41 catalysts. There was a slight increase of the wall thickness in the Ga or Al containing materials, when compared with Si-MCM-41. These results could suggest that there was a modification of the structure, probably due to the introduction of these elements in the framework [56]. Fig. 2 shows the nitrogen adsorptiondesorption isotherms of the different solids. All the isotherms are of type IV and exhibit three stages. The first stage is due to monolayer adsorption of nitrogen to the walls of the mesopores at a low relative pressure $\left(\mathrm{P} / \mathrm{P}_{0}<0.25\right)$. The second stage is characterized by a steep increase in adsorption $\left(0.25<\mathrm{P} / \mathrm{P}_{0}<0.4\right)$. As the relative pressure increases, the isotherm exhibits a sharp inflection, characteristic of capillary condensation within the uniform mesopores. The third stage $\left(\mathrm{P} / \mathrm{P}_{0}>0.4\right)$ in the adsorption isotherm is the gradual increase in volume with $\mathrm{P} / \mathrm{P}_{0}$, due to multilayer adsorption on the outer surface of the particles. The BJH pore size distribution curves for $\mathrm{Si}-\mathrm{Al}$ - or Ga-MCM-41 are shown in 
Fig.S1 (see supporting information). The mesoporous materials Si- or Al-MCM-41 have narrow mesopore size distribution ; in the case of Ga-MCM-41, the BJH pore size distribution further indicates the presence of irregular mesopores. These results are well correlated to the XRD data which already revealed less ordered structure for Ga-MCM-41 solids.

It could be seen from Table 1 that the pore diameter of samples increased gradually in the following sequence Si-MCM-41 < Al-MCM-41 < Ga-MCM-41, which suggested generally that heteroatoms incorporation would result in a shift to higher pore size [9].

On the other hand, the pore volume and BET surface area decreased basically for Ga-MCM41. Such decrease in the SSA when gallium was introduced could be partly related to the presence of extra-framework gallium species with lower specific surface area and thus lowering the overall surface area of the final material [57].

The FTIR spectra of the calcined and as-synthesized samples are given in Fig.S2 (see supporting information). The presence of absorption bands around 2921 and $2851 \mathrm{~cm}^{-1}$ for the as-synthesized materials corresponds to asymmetric and symmetric $\mathrm{CH}_{2}$ vibrations of the surfactant molecules. The infrared spectrum of the calcined samples indicates a broad envelop around $3500 \mathrm{~cm}^{-1}$, due to $\mathrm{O}-\mathrm{H}$ stretching of surface hydroxyl groups, bridged hydroxyl groups and adsorbed water molecules, while deformational vibrations of adsorbed molecules cause the adsorption bands at $1626-1638 \mathrm{~cm}^{-1}$. The peaks between 1247 and $1072 \mathrm{~cm}^{-1}$ are attributed to the asymmetric stretching of $\mathrm{T}-\mathrm{O}-\mathrm{T}(\mathrm{T}=\mathrm{Ga}$ or $\mathrm{Al})$. Other groups are observed around 800 and $544 \mathrm{~cm}^{-1}$ and the peak at $460 \mathrm{~cm}^{-1}$ is due to the bending mode of T-O-T.

The thermal properties of the samples were investigated by TGA (Fig. 3). The initial weight loss up to $120^{\circ} \mathrm{C}$ is due to desorption of physically adsorbed water. The weight loss from 120 to $350{ }^{\circ} \mathrm{C}$ is due to organic template. The oxidative desorption of the organic template takes place at $180{ }^{\circ} \mathrm{C}$ and the minute quantity of weight loss above $350-550{ }^{\circ} \mathrm{C}$ is related to water 
loss from the condensation of adjacent $\mathrm{Si}-\mathrm{OH}$ groups to form siloxane bonds. The loss in mass varies according to the following order Si-MCM-41 > Ga-MCM-41>Al-MCM-41.

From the TGA results, one can deduce that the organic template associated with the silanol groups in pure silica MCM-41 can be easily removed at lower temperatures whereas, for the Al-MCM-41 samples, the template has to be removed at higher temperatures due to the stronger interaction of the organic template with the aluminum species.

SEM and TEM images of the calcined samples Si- Al- or Ga-MCM-41 are shown in Fig. 4. This information could be required to assess any relationship between catalytic activity and their morphologies. The SEM pictures of the samples are typical of silicate mesoporous materials and show a different morphology with some large elongated agglomerates.

Whereas Ga-MCM-41 exhibits particles irregular shape between $0.5-2 \mu \mathrm{m}, \mathrm{Si}$ - or Al-MCM41 have particle size between 1-2.5 $\mu \mathrm{m}$.

The TEM images show that the Si- or Al-MCM-41 mesoporous catalysts display highly ordered honeycomb-like regular arrangement of hexagonal pores. The TEM pictures of the calcined catalysts are presented in Fig. 4. In the case of Ga-MCM-41, the TEM analysis shows pores of irregular form. These results are in agreement with nitrogen sorption measurements and XRD analysis.

\subsection{Catalytic experiments}

By reaction of 4-nitrophenyl azide (1, 1 equiv.) with the activated alkenes 2 (2 equiv.) in the presence of triethylamine ( 2 equiv.), and using DMF as the solvent, the 1,2,3-triazoles 3ae were isolated in moderate to high yields after $24 \mathrm{~h}$ reaction time at room temperature (Table 2). The reaction proved regioselective. The assignment of the stereochemistry was established by NMR (NOESY, HMBC, and HMQC) and was confirmed by XRD [50]. 
catalysis. Table 3 depicts the results using both homogeneous $\left(\mathrm{Et}_{3} \mathrm{~N}\right)$ and heterogeneous (MCM-41) basic catalysts. When compared with triethylamine alone (Table 2), the evaluated mixtures exhibit a very important activity, with very high yields and, except for 3d, shorter reaction times ( 0.5 to $2 \mathrm{~h}$, Table 3$)$. In the case of homogenous/heterogeneous catalysis using the calcined or as-synthesized mesoporous materials Si- Ga- or Al-MCM-41, 4-nitrophenyl azide (1) was simply added to the activated alkenes 2 (2 equiv.) in the presence of both triethylamine (2 equiv.) and a catalytic amount (10 mol\%) of Si- Ga- or Al-MCM-41, using DMF as solvent. The products were collected and washed with water. To remove the catalyst, the precipitate was extracted with acetone, and the solvent was then removed. Good results were obtained under these conditions from 4-nitrophenyl azide (1) and all the activated alkenes 2 using Et ${ }_{3} \mathrm{~N} /$ calcined mesoporous material Si-MCM-41 (Table 3, entries 21-25). By using $\mathrm{Et}_{3} \mathrm{~N} /$ calcined Ga- or Al-MCM-41 (Table 3, entries 1-5 and 11-15), Et ${ }_{3} \mathrm{~N} /$ as-synthetized Si-MCM-41 (Table 3, entries 26-30) and Et ${ }_{3}$ N/as-synthetized Ga- or Al-MCM-41 (Table 3, entries 6-10 and 16-20), good yields were still observed using acetylacetone (2a), methyl acetoacetate (2b) and malonodinitrile (2e). However, when using ethyl acetoacetate (2c) and $\alpha$-benzoylacetophenone (2d), moderate yields were noted. After recourse to a $24 \mathrm{~h}$ contact in the case of $\mathbf{2 d}$, the product $\mathbf{3 d}$ was purified by column chromatography and isolated in yields ranging from 47 to $84 \%$. The use of the mixtures $\mathrm{Et}_{3} \mathrm{~N} /$ as-synthesized or calcined Si-MCM-41 catalyst led to higher yields than the other catalysts.

For the products $\mathbf{3 d}$ and $\mathbf{3 e}$, if we compare the results obtained using the mixture of basic catalysts (Table 3 ) with those obtained by homogeneous basic catalysis (Table 2), we can note that the reaction times are reduced and that the yields are always improved using the mixtures of Si- Ga- or Al-MCM-41 (10 mol\%) with the $\mathrm{Et}_{3} \mathrm{~N}$ homogeneous catalyst (2 mmol). These 
results suggest that the triethylamine is entrapped in the mesoporous materials [57], and acts as a supported catalyst for this reaction.

Cycloaddition reaction using a heterogeneous catalysis. As-synthesized M-MCM-41 $(\mathrm{M}=\mathrm{Si} \mathrm{Ga}$ or $\mathrm{Al})$ materials were also used as base catalysts without adding triethylamine (Fig. 5 and Table 4).

\section{- Effect of the amount of catalyst}

In order to understand the influence of the heterogeneous catalysts on the cycloaddition reaction, reactions between 4-nitrophenyl azide (1, 1 equiv.) and acetylacetone (2a, 1 equiv.) were performed using different amounts of as-synthesized Ga-MCM-41 (Fig. 5). Using 10 mol\% of as-synthesized Ga-MCM-41 led to a very low 5\% yield for $24 \mathrm{~h}$ reaction time. This result contrasts with the $90 \%$ yield obtained using the same amount of catalyst in the presence of triethylamine for a shorter $1.5 \mathrm{~h}$ reaction time (Table 3, entry 6), and suggests a synergic effect between triethylamine and the as-synthesized mesoporous material. One can notice in Fig. 5 that increasing the amount of catalyst has an impact on the reaction yield. Indeed, a 24 h reaction time led to a 75\% yield using $20 \mathrm{~mol} \%$ (and 92\% yield using $25 \mathrm{~mol} \%$ ) of assynthesized Ga-MCM-41. The yield obtained after one hour of reaction in the presence of $20 \%$ of catalyst is low about $7 \%$. Thus, the reaction time can been minimized due to an increased reactivity using both catalysts $\mathrm{Et}_{3} \mathrm{~N}$ and as-synthesized Ga-MCM-41.

\section{- Cycloaddition reaction using Si- Ga- or Al-MCM-41 catalysts}

As expected no products were detectable by using $25 \mathrm{~mol} \%$ of calcined Si- Ga- or AlMCM-41 as catalyst for the reaction between 4-nitrophenyl azide (1, 1 equiv.) and acetylacetone (2a, 1 equiv.) (results not shown). In contrast, very high yields were obtained for the products 3a-c with a reaction time not more than $0.25 \mathrm{~h}(15 \mathrm{~min})$ when using 25 mol\% of as-synthesized Si-MCM-41 (Table 4). The latter is more active than as-synthesized Ga- or Al-MCM-41, Et ${ }_{3} \mathrm{~N}$ and the mixed catalyst in these three reactions (results not shown). 
The basic properties exhibited by as-synthesized Si- Ga- or Al-MCM-41 are due to the presence of siloxy anions $\left(\equiv \mathrm{SiO}^{-}\right)$, which exist in combination with the cationic surfactant. Indeed, the existence of the ionic pair $\left(\equiv \mathrm{SiO}^{-}, \mathrm{CTA}^{+}\right)$has been demonstrated by many researchers [35,58,59]. For instance, Oliveira and al studied a variety of as-synthesized molecular sieves and assessed that they have basic sites and can be employed as catalysts for Knoevenagel condensation under mild conditions [35]. Their catalytic activity is mostly dependent on the fraction of silicon framework. Pure siliceous molecular sieves are suggested to contain the highest number of siloxy anions, which are the strong basic sites. The occluded organic cations can interact with the molecular sieves framework, providing the high catalytic activity. Calcined siliceous molecular sieves, which have only silanol groups, show a lower activity. The catalytic activity difference between $\mathrm{Si}-\mathrm{Ga}$ - or Al-MCM-41 could be caused by a higher concentration of siloxy anions in Si-MCM-41 since it has more silica than Ga- or AlMCM-41 (see EDX results).

Koller et al. [60] have also synthesized MFI zeolites with different amounts of silicon and showed that increasing the content of this element increases the amount of siloxy anion. The same remarks were pointed out by Oliveira et al [35]. Srivastava et al. also noticed similar behavior in their work, using Si, Al-BEA and Si-MCM-41 [33]. When they carried out their reaction over as-synthesized $\mathrm{Si}, \mathrm{Al}$-BEA catalyst, they had to use three times the amount of the catalyst than that used for siliceous Si-MCM-41 to achieve comparable conversions.

From the three tested catalysts, Si-MCM-41 mesoporous silica showed to have the highest catalytic activity in the cycloaddition reaction. This result is well correlated to the physicochemical characterizations of these materials (DRX, EDX, $\mathrm{N}_{2}$ sorption) and also to their range of features: (1) they are siliceous materials containing a high number of siloxy anion, 
(2) capacity of the large pores to hold higher amounts of surfactant, which are cationic $\mathrm{CTA}^{+}$ in concert with siloxy anions [58], (3) $\mathrm{CTA}^{+}$cations are bulky organic cations (low charge/volume ratio) and this means that their interaction with the catalytic active sites, i.e. siloxy anions, is weaker.

We have demonstrated using TGA analysis that removal of the surfactant $\left(\mathrm{CTA}^{+}\right)$in the Si-MCM-41 is easier compared to Ga or Al-MCM-41, which means that the interaction between the silica matrix and $\mathrm{CTA}^{+}$is low whereas in the case of $\mathrm{Ga}$ or Al-MCM-41 the interaction between the heteroatom-containing matrix and $\mathrm{CTA}^{+}$is important. EDX analysis also shows that the incorporation of aluminum is more important compared to the gallium thus the Ga-MCM-41 has a high number of siloxy compared to Al-MCM-41 (see table 1).

Otherwise, triethylamine is at the origin of the irreversible water elimination step [50]. The latter may displace the reaction towards the formation of the final triazole, and thus help to perform more difficult reactions such as that giving $\mathbf{3 e}$ (absence of intramolecular hydrogen bond to favor the enimine form).

Using triethylamine alone leads to an efficient reaction, except from $\alpha$ benzoylacetophenone (2d) and malonodinitrile (2e). Whereas for the former steric hindrance can be proposed to rationalize the low yield, the absence of intramolecular hydrogen bond to favor the enimine form can be advanced for the latter.

Using triethylamine in the presence of $10 \%$ of MCM-41 allowed the yields of $\mathbf{3 d}$ and $\mathbf{3 e}$ to be improved. In the case of $\mathbf{3 d}$, calcined Si-MCM-41, which possesses a larger surface area, proved the most efficient catalyst. The presence of surfactant inside the mesopores, by decreasing the available surface, reduces the catalyst activity. In the case of $\mathbf{3 e}$, the yield is increased whatever the catalyst employed. The latter can either favor the formation of the enimine form or the 1,3-dipolar cycloaddition through coordination of the dipolarophile nitrogen to the catalyst metal. 
Without triethylamine, using as-synthesized MCM-41 catalysts in a sufficient amount (25 mol\%) provides the triazoles 3a-c (for which the enol forms are favored due to intramolecular hydrogen bond) in good yields. In this case, the triethylamine effect can be restored by the siloxy anions contained in as-synthesized MCM-41 catalysts. Substrate and intermediate product size seems to be a limit of the system (products $\mathbf{3 d}$ and $\mathbf{3 e}$ ), with better yields noted for Si-MCM-41.

If we compare our materials with others catalysts, the as-synthesized Si-MCM-41 catalyst seems to be the best for the reactions of cycloaddition $[29,45]$. In fact, not only the reaction time is decreased (around $15 \mathrm{~min}$ ), but also the Si-MCM-41 is used as synthesized thus no further preparation is needed.

\section{- Catalyst reusability}

Reusability of the catalysts has been studied in the cycloaddition of 4-nitrophenyl azide (1) under the following conditions: 4-nitrophenyl azide (1, $1 \mathrm{mmol})$, acetylactone $(\mathbf{2 a}, 1$ mmol), as-synthesized Si- Ga- or Al-MCM-41 (25 mol\%), DMF (2 ml), room temperature, $0.25 \mathrm{~h}$ reaction time for Si-MCM-41, $1 \mathrm{~h}$ for Ga-MCM-41 and $24 \mathrm{~h}$ for Al-MCM-41. The catalysts were filtered, washed with DMF and dried before use in the following cycles, the results are represented in the figure 6 .

The catalyst could be reused up to five times with little loss of activity, confirming its stability as seen by TGA and XRD data (fig.3S and fig.4S see supplementary data). Indeed, the results obtained by the TGA analysis (fig. $3 \mathrm{~S}$ see supplementary data) indicate that there is a weak $\mathrm{CTA}^{+}$leaching from the reaction medium (for example ca. $0.2 \%$, after five use of as-synthesized Si-MCM-41). This mass loss is probably responsible for the slight reduction of the catalyst activity. Concerning the results obtained by XRD analysis (fig.4S see supplementary data) we note that there was a small decrease in the intensity of all 
characteristic peaks of MCM-41, may be due to the influence of the solvent on the CTA containing mesoporous materials [56].

\section{Conclusion}

Si- Ga or Al-MCM-41 molecular sieves have been successfully prepared by a direct synthesis method. The samples exhibited high structural regularity and surface area values, EDX results showed a more important incorporation of aluminum into the framework of MCM-41 compared to gallium.

Three types of catalysts were compared in the course of the thermal cycloaddition of aryl azides with activated alkenes, i.e. homogeneous [50], heterogeneous and mixed homogeneous/heterogeneous catalysts. Concerning the latter two catalysts, the reaction time and product yields of 3a-c have been improved in the following order: heterogeneous catalyst $>$ mixed catalyst $>$ homogeneous catalyst and, for the products $\mathbf{3 d}$ and $\mathbf{3 e}$, the homogeneous/heterogeneous catalysis was superior than the catalysts used individually. This later result may be explained by a synergic effect between $\mathrm{Et}_{3} \mathrm{~N}$ and the mesoporous material.

The as-synthesized Si-MCM-41 is particularly efficient for the cycloaddition reaction at room temperature due to its higher number of ionic pairs $\equiv \mathrm{SiO}^{-} \mathrm{CTA}^{+}$.

The incorporation of moderate amount of heteroatoms such as $\mathrm{Al}$ or $\mathrm{Ga}$ in the silica framework would allow the mesoporous solids to benefit from enhanced hydrothermal stability a feature particularly needed in reactions operating in aqueous media. Unfortunately, heteroatom incorporation reduces the number of siloxy and decreases the basic character.

In conclusion, we have developed a convenient method for the synthesis of 1,2,3-triazoles, which can serve as useful building blocks for useful targets, by Si-MCM-41-catalyzed cycloaddition of aryl azides with activated alkenes in very high yields. This one-pot synthesis of 1,2,3-triazoles using a heterogeneous catalytic system benefits from considerable synthetic 
advantages, such as mild reaction conditions, easy availability of starting materials, short durations of reaction $(15 \mathrm{~min})$, simplicity of the reaction procedure, efficient catalyst regeneration and reuse for new reaction cycle.

\section{REFERENCES:}

[1] M.E. Davis, Nature 417 (2002) 813-821.

[2] I. Izquierdo-Barba, S. Sánchez-Salcedo, M. Colilla, M.J. Feito, C. Ramírez-Santillán, M.T. Portolés, M. Vallet-Regí, Acta Biomaterialia 7 (2011) 2977-2985.

[3] P. Selvam, S.K. Bhatia, C.G. Sonwane, Ind. Eng. Chem. Res. 40 (2001) 3237-3261.

[4] S. Haddoum, I. Fechete, B. Donnio, F. Garin, D. Lutic, C.E. Chitour. Catal. Comm. 27 (2012) 141-147.

[5] J.J. Zou, Y. Liu, L. Pan, L. Wang, X. Zhang. Appl. Catal. B: Environmental 95 (2010) 439-445.

[6] J. Lin, B. Zhao, Y. Cao, H. Xu, S. Ma, M. Guo, D. Qiao, Y. Cao. Appl. Catal. A: General 478 (2014) 175-185.

[7] I. Fechete, B. Donnio, O. Ersen, T. Dintzer, A. Djeddi, F. Garin. Appl. Surf. Sci. 257 (2011) 2791-2800.

[8] B. Boukoussa, R. Hamacha, A. Morsli, A. Bengueddach, Arab. J. Chem. (2013), http://dx.doi.org/10.1016/j.arabjc.2013.07.049.

[9] J. M. Campos, J. P. Lourenço, A. Fernandes, M. Rosário Ribeiro. Catal. Comm. 10 (2008) $71-73$.

[10] A. Benhamou, J.P. Basly, M. Baudu, Z. Derriche, R. Hamacha, J. Colloid Interface Sci. 404 (2013) 135-139.

[11] S.A. Idris, S.R. Harvey, L.T. Gibson, J. Hazard. Mater. 193 (2011) 171-176.

[12] S. Yan, L. Xiu-Wu, S. Wei, Z. Yaping, Z. Li, Appl. Surf. Sci. 253 (2007) 5650-5655. 
446

447

448

449

450

451

452

453

454

455

456

457

458

459

460

461

462

463

464

465

466

467

468

469

[13] G. Maria, A.I. Stoica, I. Luta, D. Stirbet, G. L. Radu, Micro. Meso. Mater. 162 (2012) 80-90

[14] H. Yu, H. Zhang, W. Yang, J. Feng, W. Fan, S. Song, Micro. Meso. Mater. 170 (2013) $113-122$.

[15] X. Liu, H. Sun, Y. Yang, J. Colloid Interface Sci. 319 (2008) 377-380.

[16] P.R. Selvakannan, K. Mantri, J. Tardio, S.K. Bhargava, J. Colloid Interface Sci. 394 (2013) 475-484.

[17] B.P. Ajayi, B. Rabindran Jermy, K.E. Ogunronbi, B.A. Abussaud, S. Al-Khattaf, Catal. Today 204 (2013) 189-196.

[18] E. Martínez-Belmonte, J. Aguilar, M. Gutierrez, J.A. Montoya, J.A. De los Reyes, M. Torres, L.F. Chen, Catal. Today 212 (2013) 45-51.

[19] N. Saadatjoo, M. Golshekan, S. Shariati, H. Kefayati, P. Azizi, J. Mol. Catal. A: Chem. 377 (2013) 173-179.

[20] B. Qi, Y. Wang, L.L. Lou, L. Huang, Y. Yang, S. Liu, J. Mol. Catal. A: Chem. 370 (2013) 95-103.

[21] E. Rezaei, J. Soltan, Chem. Eng. J. 198-199 (2012) 482-490.

[22] D. Zhang, R. Wang, L. Wang, X. Yang, J. Mol. Catal. A: Chem. 366 (2013) 179-185.

[23] E.G. Vaschetto, G.A. Monti, E.R. Herrero, S.G. Casuscelli, G.A. Eimer, Appl. Catal. A: Gen. 453 (2013) 391-402.

[24] C.N. Pérez, E. Moreno, C.A. Henriques, S. Valange, Z. Gabelica, J.L.F. Monteiro, Micro. Meso. Mater. 41 (2000) 137.

[25] S. Ernst, T. Bongers, C. Casel, S. Munsch, in: I. Kiricsi, G. Pál-Borbély, J.B. Nagy, H.G. Karge (Eds.), Porous Materials in Environmentally Friendly Processes, Studies in Surface Science and Catalysis, vol. 125, Elsevier, Amsterdam, 1999, p. 367. 
470

471

472

473

474

475

476

477

478

479

480

481

482

483

484

485

486

487

488

489

490

491

492

493

[26] K.R. Kloetstra, M. van Laren, H. van Bekkum, J. Chem. Soc., Faraday Trans. 93 (1997)

1211.

[27] C.-M. Yang, K.-J. Chao, J. Chin. Chem. Soc. 49 (2002) 883.

[28] F. Fajula, D. Brunel, Micro. Meso. Mater. 48 (2001) 119.

[29] S. Roy, T. Chatterjee, M. Pramanik, A. S. Ro, A. Bhaumik, Sk. Manirul Islam. J. of Molec. Catal. A: Chemical 386 (2014) 78-85.

[30] X. Wang, Y.-H. Tseng, J. C.C. Chan, S. Cheng, J. Catal. 233 (2005) 266.

[31] L. Martins, W. Hölderich, P. Hammer, D. Cardoso, J. Catal. 271 (2010) 220-227.

[32] Y. Kubota, H. Ikeya, Y. Sugi, T. Yamada, T. Tatsumi, J. Mol. Catal. A: Chem. 249 (2006) 181-190.

[33] R. Srivastava, D. Srinivas, P. Ratnasamy, Tetrahedron Lett. 47 (2006) 4213-4217.

[34] Y. Kubota, Y. Nishizaki, H. Ikeya, M. Saeki, T. Hida, S. Kawazu, M.Yoshida, H. Fujii, Y. Sugi, Micro. Meso. Mater. 70 (2004) 135.

[35] A.C. Oliveira, L. Martins, D. Cardoso, Micro. Meso. Mater. 120 (2009) 206-213.

[36] A.R. Katritzky, Z. Yuming, S.K. Singh, Heterocycles 60 (2003) 1225-1239.

[37] M.J. Genin, D.A. Allwine, D.J. Anderson, M.R. Barbachyn, D.E. Emmert, S.A. Garmon,

D.R. Graber, K.C. Grega, J.B. Hester, D.K. Hutchinson, J. Morris, R.D. Reischer, D. Stper, B.H. Yagi, J. Med. Chem. 43 (2000), 953-970.

[38] H. Wamhoff, in Comprehensive Heterocyclic Chemistry, ed. by A.R. Katritzky, C.W. Rees (Pergamon, Oxford, 1984), pp. 669-732.

[39] D.R. Buckle, C.J.M. Rockell, H. Smith, B.A. Spicer. J. Med. Chem. 29 (1986) 22622267.

[40] J.L. Kelley, C.S. Koble, R.G. Davis, E.W. Mclean, F.E. Sorako, B.R. Cooper, J. Med. Chem. 38 (1995) 4131-4134. 
[41] R.G. Mecetich, S.N. Maiti, P. Spevak, T.W. Hall, S. Yamabe, N. Ishida, M. Tanaka, T. Yamazaki, A. Nakai, K. Ogawa, J. Med. Chem. 30 (1987) 1469-1474.

[42] R. Alvarez, S. Velazquez, A. San-Felix, S. Aquaro, E. De Clercq, C.F. Perno, A. Karlsson, J. Balzarini, M.J. Camarasa. J. Med. Chem. 37 (1994), 4185-4194.

[43] R. Huisgen, Angew. Chem. 75 (1963) 604-637.

[44] V.V. Rostovtsev, L.G. Green, V.V. Fokin, K.B. Sharpless, Angew. Chem. Int. Ed. 41 (2002) 2596-2599.

[45] I. Jlalia, F. Gallier, N. Brodie-Linder, J. Uziel, J. Augé, N. Lubin-Germain, J. Molec. Catal. A: Chemical 393 (2014) 56-61.

[46] S. Chassaing, M. Kumarraja, A. Sani Souna Sido, P. Pale, J. Sommer, Org. Lett. 9 (2007) 883-886.

[47] B.H. Lipshutz, B.R. Taft, Angew. Chem. Int. Ed. 45 (2006) 8235-8238.

[48] S. Brunauer, P.H. Emmett, E. Teller, J. Am. Chem. Soc. 60 (1938) 309-319.

[49] E.P. Barrett, L.G. Joyner, P.H. Halenda, J. Am. Chem. Soc. 73 (1951) 373-380.

[50] S. Zeghada, G. Bentabed-Ababsa, A. Derdour, S. Abdelmounim, L.R. Domingo, J.A. Saez, T. Roisnel, E. Nassar, F. Mongin, Org. Biomol. Chem. 9 (2011) 4295-4305.

[51] T.R. Pauly, Y. Liu, T.J. Pinnavaia, S.J.L. Billinge, T.P. Rieker, J. Am. Chem. Soc. 121 (1999) 8835-8842.

[52] C-F.Cheng, H.He, W.Zhou, J. Klinowski, J.A.S.Goncalves, L.F. Gladden, J. Phys. Chem., 100(1996)390.

[53] K.Okumura, K. Nishigaki, M. Niwa, Micro. Meso. Mater., 44-45 (2001), 509-516.

[54] B. Jarry, F. Launay, J.P. Nogier, V. Montouillout, L. Gengembre, J.L. Bonardet, Appl. Catal. A. 309 (2006) 177-186.

[55] H.Y. Lin, Y.L. Pan, Y.W. Chen, J. Porous Mater. 12 (2005) 151-164.

[56] X. Yang, Q. Guan, W. Li, J. Env. Mana. 92 (2011) 2939-2943. 
519

520

521

522

523

524

525

526

527

528

529

530

531

532

533

534

535

536

537

538

539

540

541

542

543

[57] Z. El Berrichi, L. Cherif, O. Orsen, J. Fraissard, J.-P Tessonnier, E. Vanhaecke, B. Louis, M.-J. Ledoux, C. Pham-Huu, Appl. Catal. A: General 298 (2006) 194-202

[58] L. Martins, T.J. Bonagamba, E.R. Azevedo, P. Bargiela, D. Cardoso, Appl. Catal. A: Gen. 312 (2006) 77-85.

[59] N. Baccile, G. Laurent, C. Bonhomme, P. Innocenzi, F. Babonneau, Chem. Mater. 19 (2007) 1343-1354.

[60] H. Koller, R.F. Lobo, S.L. Burkett, M.E. Davis, J. Phys. Chem. 99 (1995) 12588.

6

(1)

8

9

\section{Figure caption}

Fig.1. XRD patterns of as-synthesized and calcined Si- Ga- or Al-MCM-41, (a): Ga-MCM-41 and (b): Al-MCM-41. (c) Si-MCM-41

Fig.2. Nitrogen adsorption-desorption isotherms of calcined Si- Ga- or Al-MCM-41 materials.

Fig.3. TGA analysis curves for as-synthesized Si- Ga- or Al-MCM-41 mesoporous materials photomicrographs of calcined (a) Ga-MCM-41 and (b) Al-MCM-41.

Fig.4. SEM and TEM images of calcined Si- Ga- or Al-MCM-41 mesoporous materials: $(a, b, c)$ SEM images, $(d, e, f)$ TEM images.

Fig.5. Effect of the catalyst amount (as-synthesized Ga-MCM-41) on the yield of 3a.

Fig.6. Catalyst reusability. Reaction conditions: 4-nitrophenyl azide (1, 1 mmol), acetylacetone (2a, $1 \mathrm{mmol})$, catalyst (25 mol \%), DMF (2 $\mathrm{mL})$, room temperature, reaction time: $0.25 \mathrm{~h}(15 \mathrm{~min})$ for Si-MCM-41, $1 \mathrm{~h}$ for Ga-MCM-41 and $24 \mathrm{~h}$ for AlMCM-41 (at the end of the reaction, the catalyst is dried and reused). 
Table 1. Physical characteristics of mesoporous catalysts.

\begin{tabular}{lcccccccc}
\hline $\begin{array}{l}\text { Catalyst } \\
\text { (calcined) }\end{array}$ & $\mathrm{Si} / \mathrm{M}^{\mathrm{a}}$ & $\mathrm{Si} / \mathrm{M}(\mathrm{EDX})^{\mathrm{b}}$ & $\mathrm{d}_{100}(\AA)$ & $\mathrm{a}_{0}(\AA)^{\mathrm{c}}$ & $\begin{array}{c}\text { Surface area } \\
\left(\mathrm{m}^{2} / \mathrm{g}\right)\end{array}$ & $\mathrm{D}^{\mathrm{d}}(\AA)$ & $\mathrm{h}^{\mathrm{e}}(\AA)$ & $\begin{array}{c}\text { Pore volume } \\
\left(\mathrm{cm}^{3} / \mathrm{g}\right)\end{array}$ \\
\hline Si-MCM-41 & $/ /$ & $/ /$ & 37.54 & 43.34 & 1430 & 35.2 & 8.14 & 1.071 \\
Al-MCM-41 & 80 & 90.74 & 41.24 & 47,61 & 1440 & 35.7 & 11.91 & 1.097 \\
Ga-MCM-41 & 80 & 100.01 & 42.42 & 48,98 & 1030 & 36.7 & 12.28 & 0.973 \\
\hline
\end{tabular}

544

$545{ }^{\mathrm{a}}$ Molar ratio in the initial gel. $\mathrm{M}=\mathrm{Ga}$ or $\mathrm{Al}$

$546{ }^{\mathrm{b}}$ Molar ratio determined by EDX analysis

$547 \quad \mathrm{c} \mathrm{a}_{0}$ means lattice parameter: $\mathrm{a}_{0}=2 \mathrm{~d}_{100} / \sqrt{ } 3$

$548{ }^{\mathrm{d}}$ Pore diameter determined by the BJH method

549 e $\mathrm{h}$ : wall thickness: $\mathrm{h}=\mathrm{a}_{0}-\mathrm{D}$ 
Table 2. Cycloaddition reaction of 4-nitrophenyl azide (1) with the activated alkenes 2 performed at room temperature.

\begin{tabular}{llllll}
\hline & & & & \\
& & & & \\
\hline
\end{tabular}

${ }^{\mathrm{a}}$ Reaction conditions: 4-nitrophenyl azide (1, $\left.1 \mathrm{mmol}\right)$, activated alkene $(2,2 \mathrm{mmol}), \mathrm{Et}_{3} \mathrm{~N}(2$ mmol), DMF (2 mL), room temperature, $24 \mathrm{~h}$ (see procedure 1).

${ }^{\mathrm{b}}$ Isolated yields. 
Table 3. Cycloaddition reaction of 4-nitrophenyl azide (1) with the activated alkenes 2 560 catalyzed under homogeneous/heterogeneous catalysis ${ }^{\mathrm{a}}$.

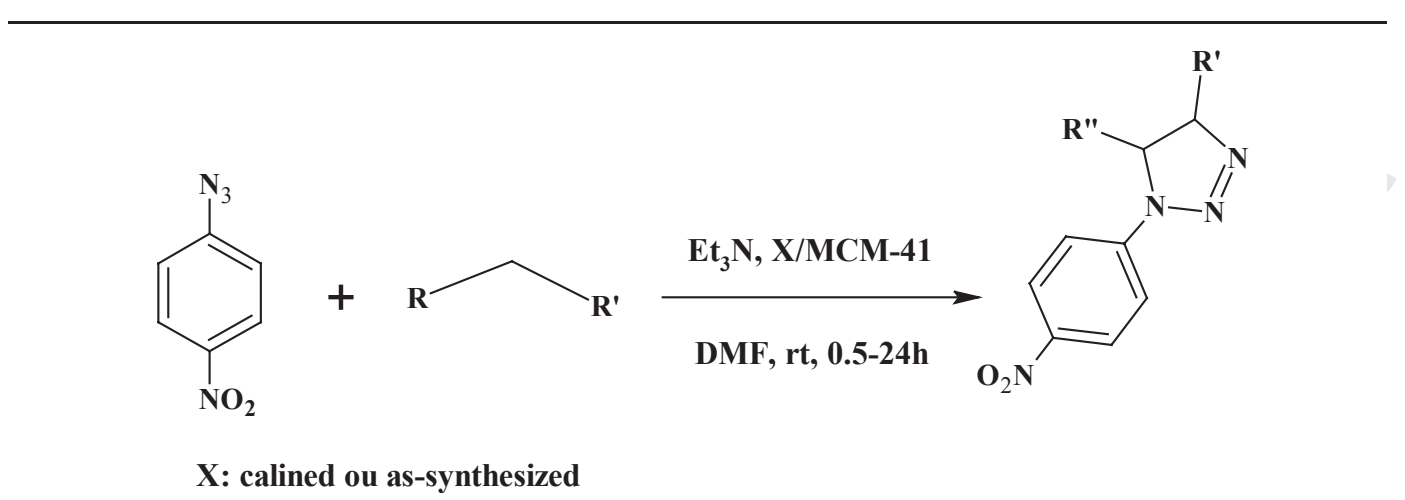

\begin{tabular}{|c|c|c|c|c|c|}
\hline Entry & 2 & Catalyst & 3 & $\mathrm{~T}(\mathrm{~h})$ & Yield $(\%)^{b}$ \\
\hline 1 & $2 a$ & \multirow{5}{*}{ calcined Ga-MCM-41 } & $3 a$ & 1.5 & 97 \\
\hline 2 & $2 \mathbf{b}$ & & $3 \mathbf{b}$ & 1.5 & 94 \\
\hline 3 & $2 c$ & & $3 c$ & 1.5 & 51 \\
\hline 4 & 2d & & 3d & 24 & 53 \\
\hline 5 & $2 e$ & & $3 e$ & 2 & 71 \\
\hline 6 & $2 a$ & \multirow{5}{*}{ as-synthesized Ga-MCM-41 } & 3a & 1.5 & 90 \\
\hline 7 & $2 \mathbf{b}$ & & $\mathbf{3 b}$ & 1.5 & 98 \\
\hline 8 & $2 c$ & & $3 c$ & 1.5 & 54 \\
\hline 9 & 2d & & 3d & 24 & 47 \\
\hline 10 & $2 e$ & & $3 e$ & 2 & 97 \\
\hline 11 & $2 a$ & \multirow{5}{*}{ calcined Al-MCM-41 } & $3 \mathbf{a}$ & 1.5 & 98 \\
\hline 12 & 2b & & $\mathbf{3 b}$ & 1.5 & 91 \\
\hline 13 & $2 c$ & & $3 c$ & 1.5 & 95 \\
\hline 14 & 2d & & 3d & 24 & 84 \\
\hline 15 & $2 e$ & & $3 \mathbf{e}$ & 2 & 88 \\
\hline 16 & $2 a$ & \multirow{5}{*}{ as-synthesized Al-MCM-41 } & $3 \mathbf{a}$ & 1.5 & 98 \\
\hline 17 & 2b & & $\mathbf{3 b}$ & 1.5 & 97 \\
\hline 18 & $2 c$ & & $3 c$ & 1.5 & 55 \\
\hline 19 & 2d & & 3d & 24 & 59 \\
\hline 20 & $2 e$ & & $3 \mathbf{e}$ & 2 & 78 \\
\hline 21 & $2 a$ & \multirow{5}{*}{ calcined Si-MCM-41 } & $3 \mathbf{a}$ & 0.5 & 98 \\
\hline 22 & 2b & & $\mathbf{3 b}$ & 0.5 & 93 \\
\hline 23 & $2 c$ & & $3 c$ & 0.5 & 95 \\
\hline 24 & 2d & & 3d & 24 & 88 \\
\hline 25 & $2 e$ & & $3 e$ & 0.5 & 92 \\
\hline 26 & $2 a$ & \multirow{5}{*}{ as-synthesized Si-MCM-41 } & $3 \mathbf{a}$ & 0.5 & 98 \\
\hline 27 & $2 \mathrm{~b}$ & & $3 b$ & 0.5 & 90 \\
\hline 28 & $2 c$ & & $3 c$ & 0.5 & 97 \\
\hline 29 & 2d & & $3 d$ & 24 & 79 \\
\hline 30 & $2 \mathrm{e}$ & & $3 e$ & 0.5 & 98 \\
\hline
\end{tabular}


a Reaction conditions: 4-nitrophenyl azide (1, $1 \mathrm{mmol})$, activated alkene (2, $2 \mathrm{mmol}), \mathrm{Et}_{3} \mathrm{~N}$ (homogeneous catalyst, $2 \mathrm{mmol}$ ), heterogeneous catalyst (10 mol\%), DMF (2 mL), room temperature (see procedure 2), 0.5-24 h.

${ }^{\mathrm{b}}$ Isolated yields.

Table 4. Cycloaddition reaction of 4-nitrophenyl azide (1) with the activated alkenes 2 catalyzed by as-synthesized Si- Ga- or Al-MCM- $41^{\text {a }}$.

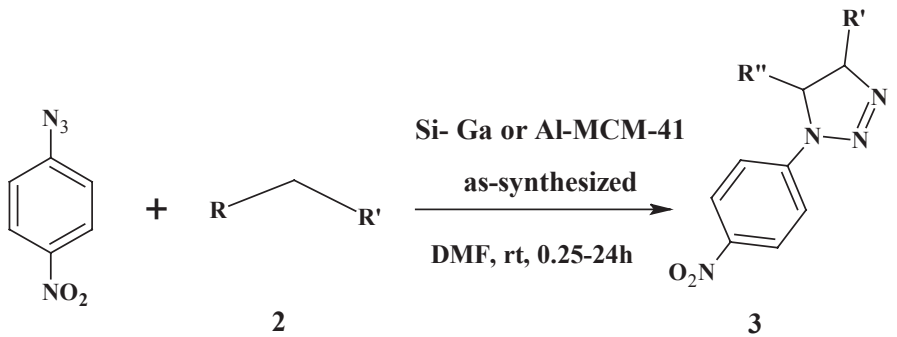

\begin{tabular}{llllll}
\hline Entry & $\mathbf{2}$ & Catalyst & $\mathbf{3}$ & $\mathrm{T}(\mathrm{h})$ & Yield (\%) \\
\hline 1 & $\mathbf{2 a}$ & & $\mathbf{3 a}$ & 1 & 92 \\
2 & $\mathbf{2 b}$ & & $\mathbf{3 b}$ & 1 & 93 \\
3 & $\mathbf{2 c}$ & as-synthesized Ga-MCM-41 & $\mathbf{3 c}$ & 1 & 94 \\
4 & $\mathbf{2 d}$ & & $\mathbf{3 d}$ & 24 & 47 \\
5 & $\mathbf{2 e}$ & & $\mathbf{3 e}$ & 24 & 9 \\
\hline 6 & $\mathbf{2 a}$ & & $\mathbf{3 a}$ & 24 & 89 \\
7 & $\mathbf{2 b}$ & & $\mathbf{3 b}$ & 24 & 61 \\
8 & $\mathbf{2 c}$ & as-synthesized Al-MCM-41 & $\mathbf{3 c}$ & 24 & 71 \\
9 & $\mathbf{2 d}$ & & $\mathbf{3 d}$ & 24 & 48 \\
10 & $\mathbf{2 e}$ & & $\mathbf{3 e}$ & 24 & 8 \\
\hline 11 & $\mathbf{2 a}$ & & $\mathbf{3 a}$ & 0.25 & 94 \\
12 & $\mathbf{2 b}$ & & $\mathbf{3 b}$ & 0.25 & 97 \\
13 & $\mathbf{2 c}$ & as-synthesized Si-MCM-41 & $\mathbf{3 c}$ & 0.25 & 90 \\
14 & $\mathbf{2 d}$ & & $\mathbf{3 d}$ & 24 & 69 \\
15 & $\mathbf{2 e}$ & & $\mathbf{3 e}$ & 18 & 55 \\
\hline
\end{tabular}

${ }^{a}$ Reaction conditions: 4-nitrophenyl azide 1 (1 mmol), activated alkene 2 (1 mmol), assynthesized Si- Ga- or Al-MCM-41 (25 mol\%), DMF (2 mL), room temperature (see procedure 3 ), reaction time $0.25-24 \mathrm{~h}$

${ }^{\mathrm{b}}$ Isolated yields. 

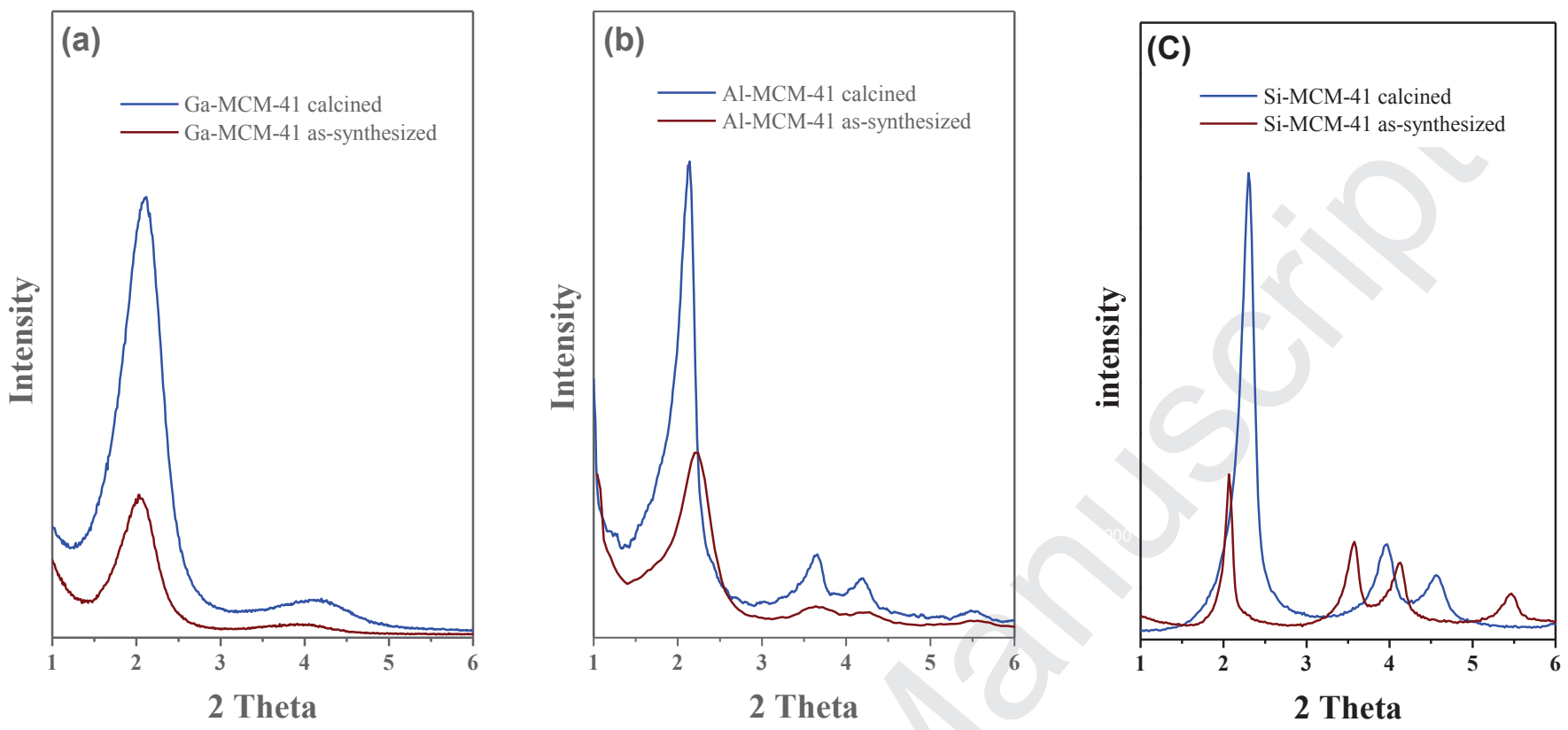

Fig 2

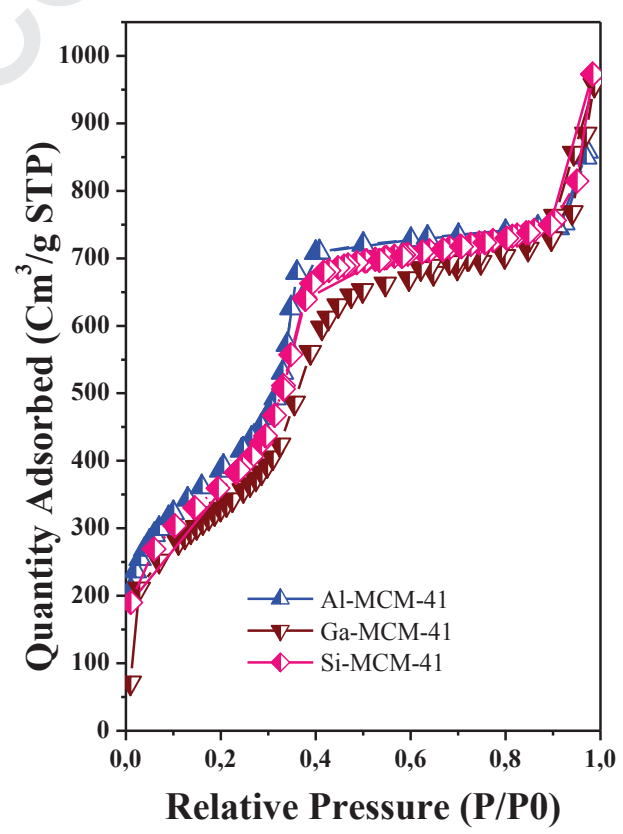




\section{Fig 3}

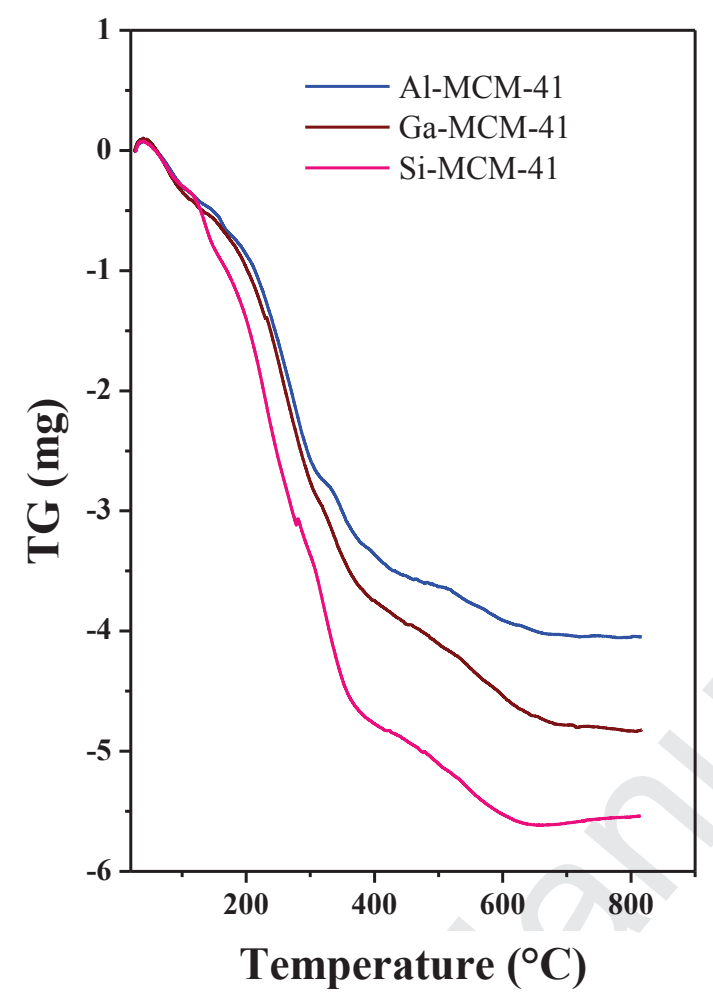


Fig 4

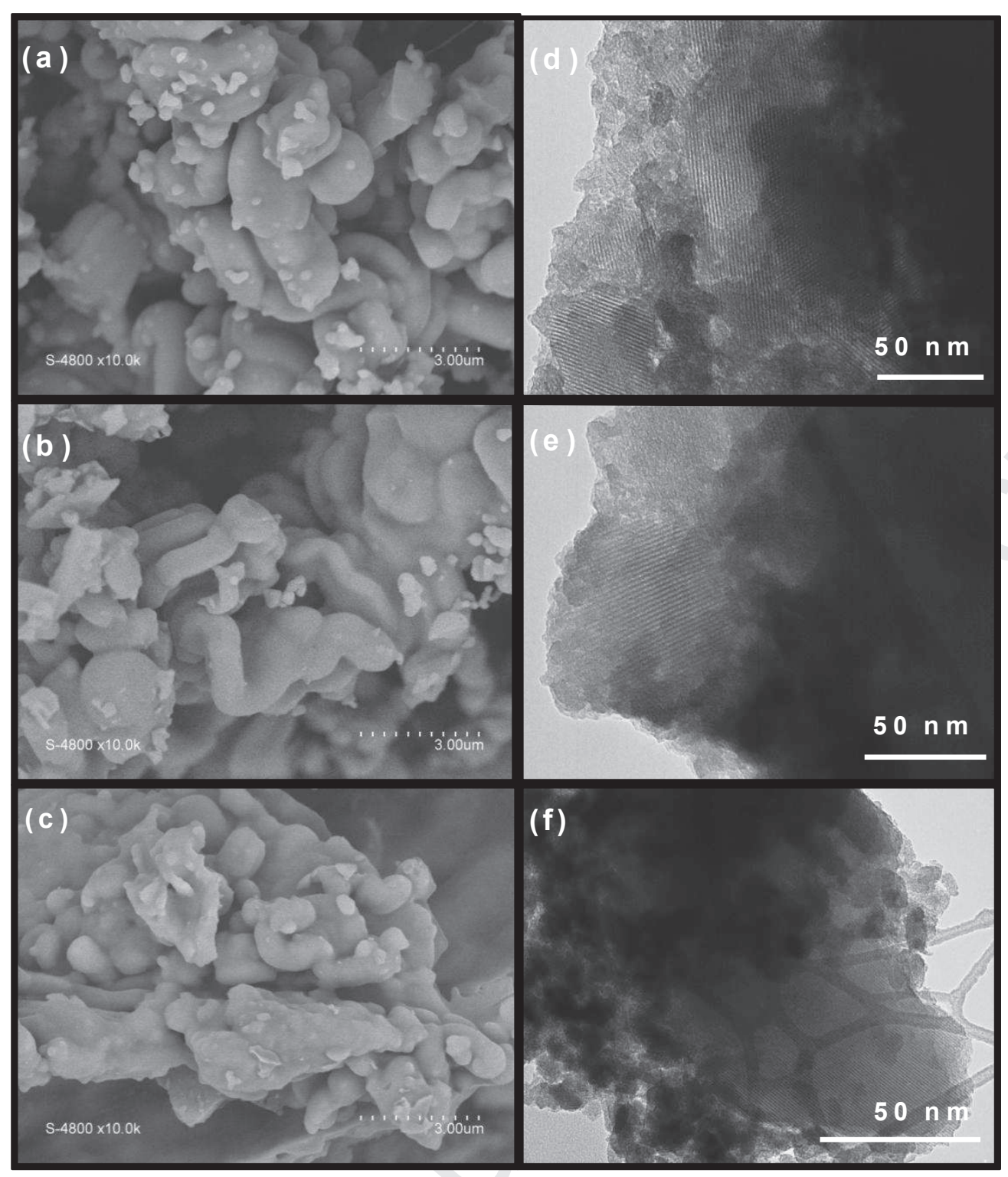

Page 31 of 32 


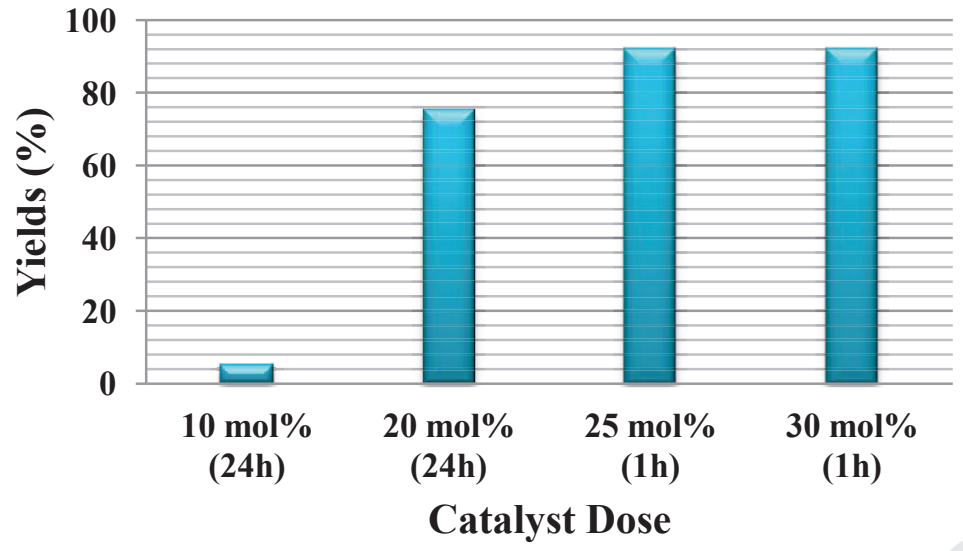

Fig 6

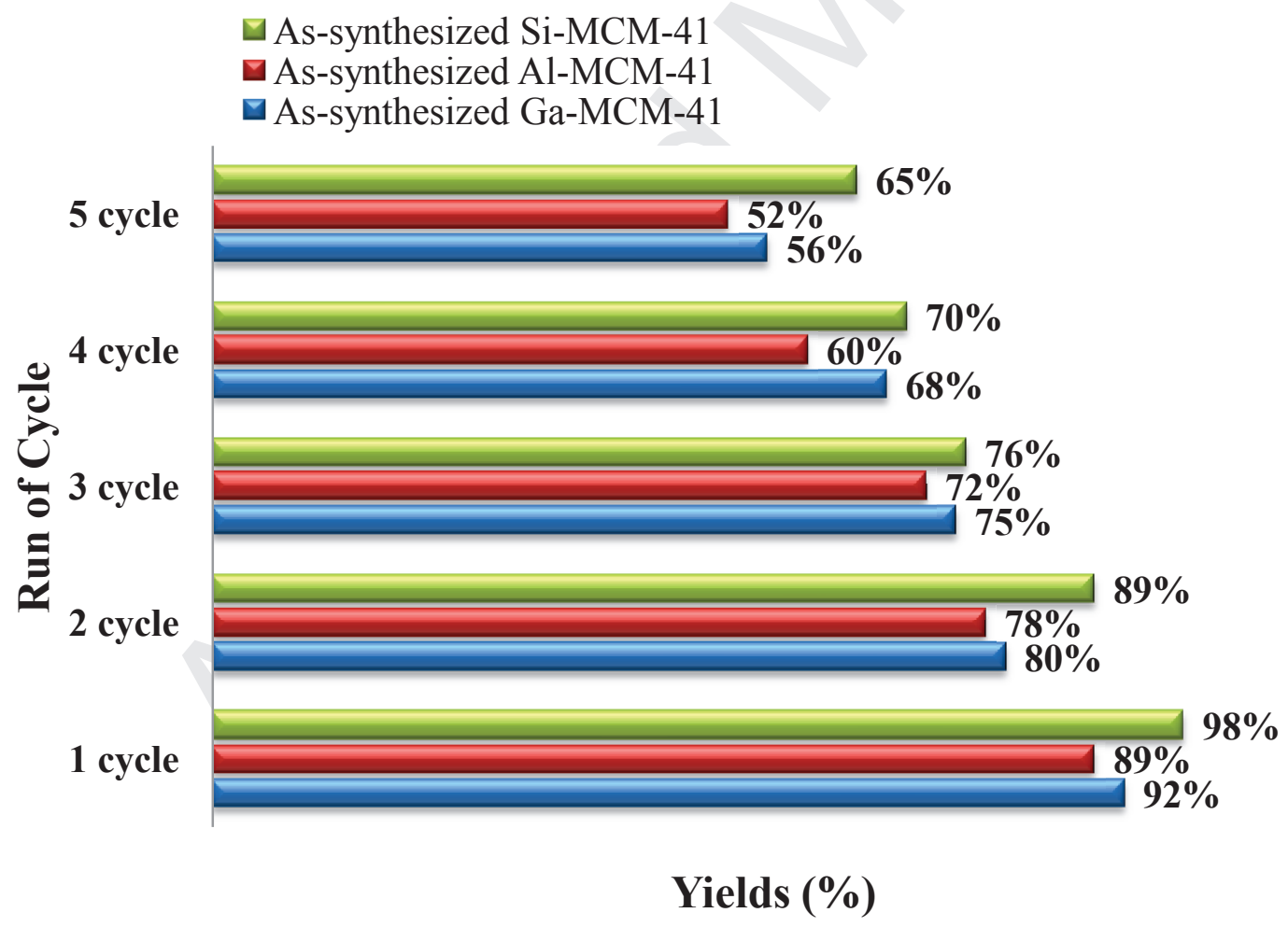

